\title{
Prevalence of vitamin D deficiency among Turkish, Moroccan, Indian and sub-Sahara African populations in Europe and their countries of origin: an overview
}

\author{
I. M. van der Meer • B. J. C. Middelkoop • \\ A. J. P. Boeke • P. Lips
}

Received: 25 February 2010 / Accepted: 7 April 2010 /Published online: 12 May 2010

(C) The Author(s) 2010. This article is published with open access at Springerlink.com

\begin{abstract}
Summary Vitamin D status of nonwestern immigrants in Europe was poor. Vitamin D status of nonwestern populations in their countries of origin varied, being either similar to the immigrant populations in Europe or higher than in European indigenous populations. Vitamin D concentrations in nonwestern immigrant populations should be improved.

Purpose The higher the latitude, the less vitamin D is produced in the skin. Most European countries are located at higher latitudes than the countries of origin of their
\end{abstract}

I. M. van der Meer • B. J. C. Middelkoop

Department of Epidemiology,

Municipal Health Service of The Hague,

The Hague, The Netherlands

B. J. C. Middelkoop

Department of Public Health and Primary Care,

Leiden University Medical Center,

Leiden, The Netherlands

\section{A. J. P. Boeke}

Department of General Practice, Institute for Health and Care Research (EMGO Institute), VU University Medical Center,

Amsterdam, The Netherlands

P. Lips

Department of Internal Medicine,

Endocrine Section and Institute for Health and Care Research

(EMGO Institute), VU University Medical Center,

Amsterdam, The Netherlands

I. M. van der Meer $(\bowtie)$

GGD Den Haag,

Postbus 12 652,

2500 DP The Hague, The Netherlands

e-mail: irene.vandermeer@denhaag.nl nonwestern immigrants. Our aim was to compare the serum 25-hydroxyvitamin D $(25(\mathrm{OH}) \mathrm{D})$ concentration of nonwestern immigrant populations with those of the population in their country of origin, and the indigenous population of the country they migrated to.

Methods We performed literature searches in the "PubMed" and "Embase" databases, restricted to 1990 and later. The search profile consisted of terms referring to vitamin $\mathrm{D}$ or vitamin D deficiency, prevalence or cross-sectional studies, and countries or ethnicity. Titles and abstracts were reviewed to identify studies on population-based mean serum 25(OH)D concentrations among Turkish, Moroccan, Indian, and sub-Sahara African populations in Europe, Turkey, Morocco, India, and sub-Sahara Africa.

Results The vitamin D status of immigrant populations in Europe was poor compared to the indigenous European populations. The vitamin D status of studied populations in Turkey and India varied and was either similar to the immigrant populations in Europe (low) or similar to or even higher than the indigenous European populations (high). Conclusions In addition to observed negative consequences of low serum 25(OH)D concentrations among nonwestern populations, this overview indicates that vitamin D status in nonwestern immigrant populations should be improved. The most efficacious strategy should be the subject of further study.

Keywords Indian · Moroccan · Prevalence $\cdot$ Serum 25-hydroxyvitamin D · Sub-Sahara African · Turkish

\section{Introduction}

Vitamin D status has been found to be poor among nonwestern immigrant populations in European countries 
compared to indigenous European populations [1-4]. The lower serum 25(OH)D concentrations among nonwestern immigrants compared to indigenous European populations may lead to differences in health. Consequences of vitamin D deficiency include bone- and muscle-related symptoms (e.g., bone and muscle pain), decreased muscle strength, and diseases (e.g., rickets in children; osteomalacia in adults) $[5,6]$. Other possible consequences are diabetes mellitus, infectious diseases, and cancer [7].

Direct sunlight stimulates the production of vitamin D in the skin from 7-dehydrocholesterol. Other sources of vitamin D include some natural foods (e.g., fatty fish), fortified foods (e.g., margarine), and supplements. The amount of vitamin D produced through exposure to UVB radiation depends on skin type: the darker the skin, the more sunlight is required to produce a given amount of vitamin D [8-10]. Nonwestern immigrants usually have darker skin than indigenous European subjects. Therefore, they have a higher risk of lower serum 25-hydroxyvitamin D $(25(\mathrm{OH}) \mathrm{D})$ concentrations when living at the same latitude.

The duration of UVB irradiation needed to produce a certain quantity of vitamin $\mathrm{D}$ in a particular skin surface depends on season, time of day, and geographical location [11]. The higher the latitude, the lower the UVB intensity, and the fewer months and hours per day during which vitamin D is produced. Most European countries are located at a higher latitude than the countries of origin of nonwestern immigrants.

The threshold for vitamin D deficiency should — ideallybe based on its consequences. However, most studies of the consequences of vitamin D deficiency have been performed among older western populations in Europe and North America, rather than among adult nonwestern immigrant populations in these countries. Another means of establishing a deficiency threshold is through the use of reference values within a population [12]. For that purpose, a comparison of the vitamin D status of nonwestern immigrant populations with the populations in their countries of origin might be more suitable than a comparison with the indigenous western populations. Our aim was to compare the vitamin D status of nonwestern immigrant populations with both the populations in their countries of origin and the populations in the country they migrated to. Additionally, we wanted to identify what determinants were mentioned to explain differences in vitamin $\mathrm{D}$ status between subgroups in the studied populations.

\section{Methods}

We performed literature searches in the "PubMed" and "Embase" databases. The search profile consisted of terms referring to vitamin D or vitamin D deficiency, prevalence or cross-sectional studies, and countries or ethnicity. The search was restricted to publications from 1990 onwards; about 1,000 were returned. Titles and abstracts were reviewed to identify studies on population-based mean serum 25(OH)D concentrations among Turkish, Moroccan, Indian, and sub-Sahara African populations in Europe, Turkey, Morocco, India, or sub-Sahara Africa. We accepted the definitions of ethnicity as used in the identified articles.

We extracted data for the Turkish, Moroccan, Indian, and sub-Sahara African populations and for the indigenous European populations if this group was included in the studies performed in Europe. From suitable publications, we extracted information about geographical location and season of data collection, age and gender of the study population, duration of pregnancy if applicable, number of subjects, mean serum $25(\mathrm{OH}) \mathrm{D}$ concentration with standard deviation, percentage of subjects with serum $25(\mathrm{OH}) \mathrm{D}<25 \mathrm{nmol} / \mathrm{l}$, and determinants of serum $25(\mathrm{OH}) \mathrm{D}$ concentration. Specific characteristics of the study population which could influence the vitamin D status, such as clothing habits, were also extracted. Of identified intervention studies, we used only data from baseline measurements. Serum $25(\mathrm{OH}) \mathrm{D}$ concentrations presented in nanogram per milliliter or microgram per liter were transformed into nanomole per liter. Data variances presented as standard errors or $95 \%$ confidence intervals were converted to standard deviations. When either vitamin D status parameter (mean and $\%<25 \mathrm{nmol} / \mathrm{l}$ ) was not presented, another measure for vitamin D status (such as median concentration or $\%$ below another threshold) was extracted.

\section{Results}

Prevalence

The identified studies on Turkish populations in Europe are presented in Table 1 and on Turkish populations in Turkey in Table 2. The vitamin D status was lower in the Turkish groups in Europe than in the indigenous European groups. Vitamin D status in the Turkish groups in Turkey varied widely. The subgroups with covering clothes had the lowest serum 25(OH)D concentrations (mean $10 \mathrm{nmol} / \mathrm{l}$ ) [13, 14]. Turkish elderly living in their own homes (mean $158 \mathrm{nmol} /$ 1 for males and $103 \mathrm{nmol} / \mathrm{l}$ for females) and Turkish unveiled adult women (mean $135 \mathrm{nmol} / \mathrm{l}$ ) -all of whom were measured at the end of summer-had the highest serum 25(OH)D concentrations $[15,16]$.

Studies on Moroccan populations in Europe are presented in Table 3. Table 4 presents the only study found on the vitamin D status of a Moroccan population in Morocco. As was the result among Turkish populations, the Moroccan populations in Europe had lower serum 25(OH)D concentrations than the indigenous European populations. The 


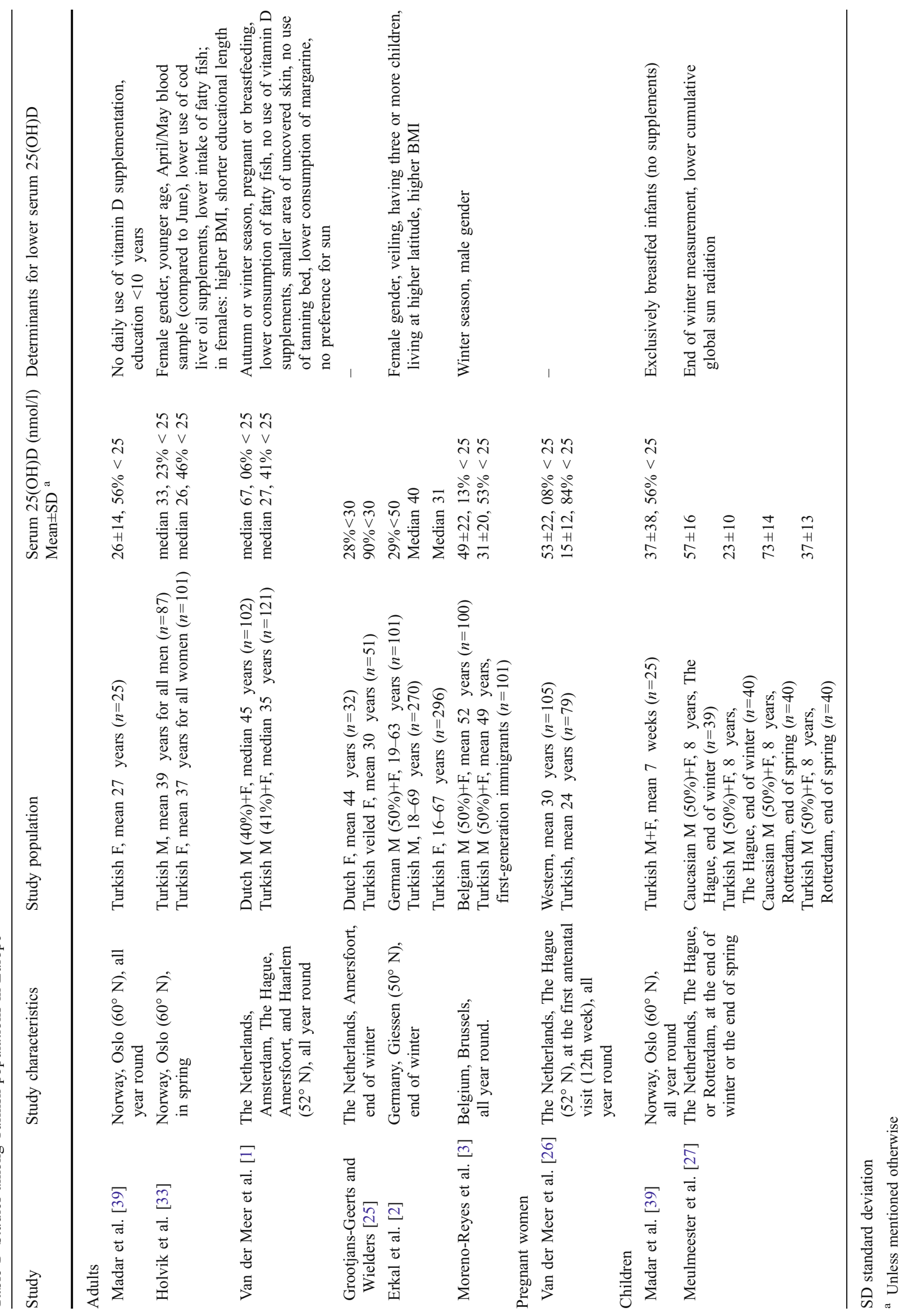




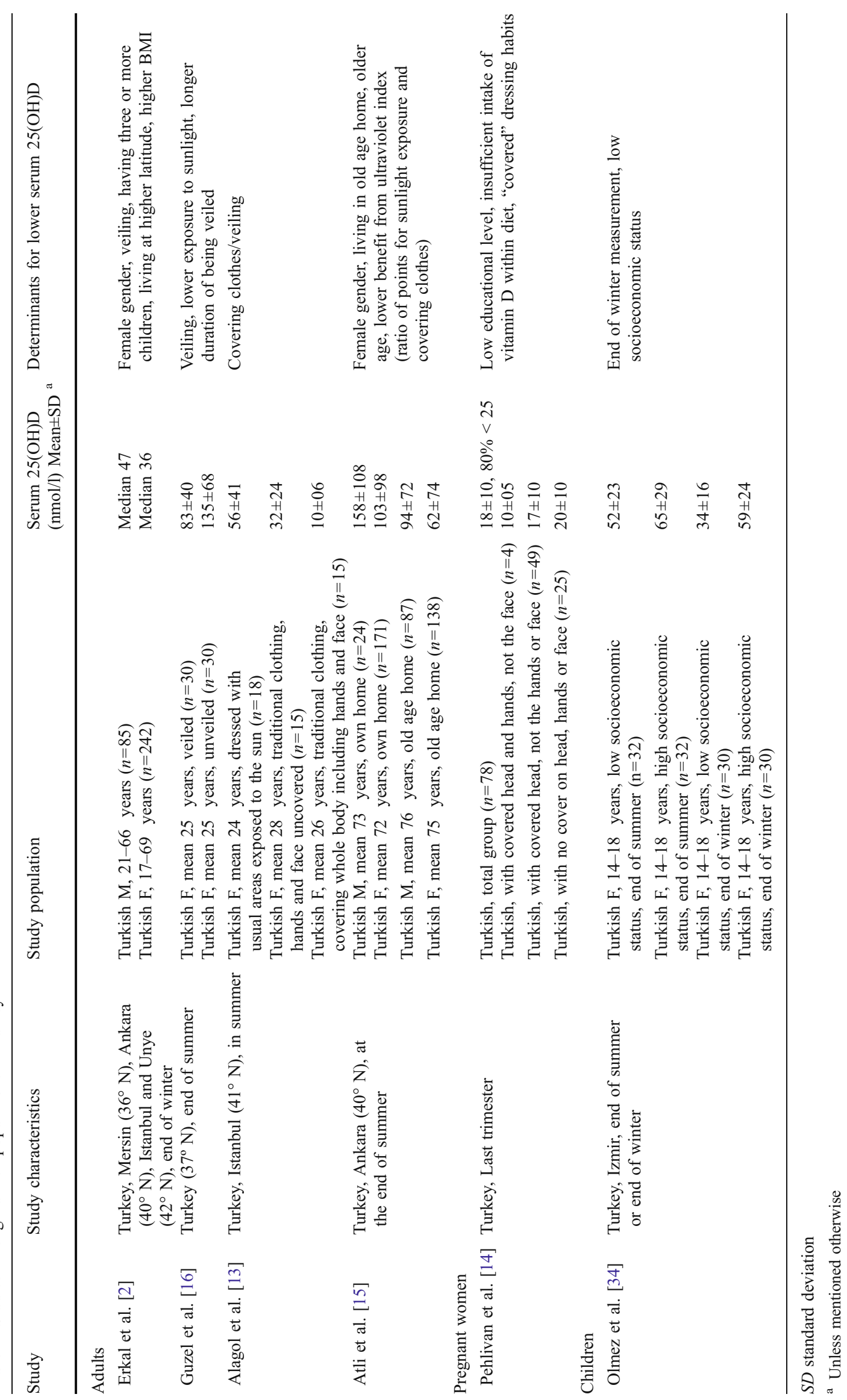




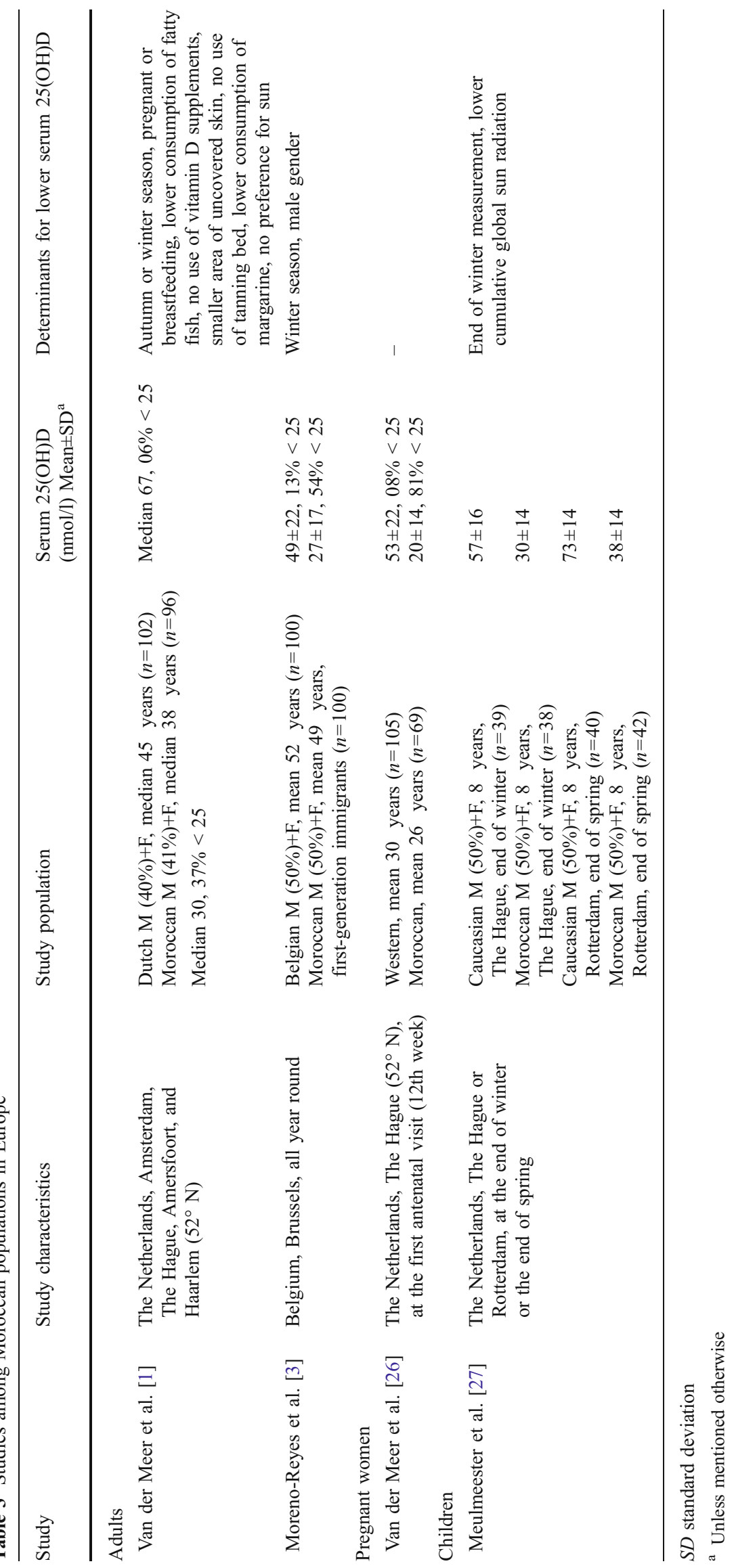


Table 4 Studies among Moroccan populations in Morocco

\begin{tabular}{llll}
\hline Study & Study characteristics & Study population & $\begin{array}{l}\text { Serum 25(OH)D Determinants for lower serum 25(OH)D } \\
(\mathrm{nmol} / \mathrm{l}) \mathrm{Mean} \pm \mathrm{SD}^{\text {a }}\end{array}$ \\
\hline Adults & Allali et al. [17] $\begin{array}{c}\text { Morocco, Rabat, in } \\
\text { the end of winter }\end{array}$ & $\begin{array}{c}\text { Moroccan F, mean } 50 \text { years, } 45 \pm 20 \\
\text { total group }(n=415) \\
\text { Moroccan F, mean 43 years, } 47 \pm 19 \\
\text { premenopausal }(n=108) \\
\text { Moroccan F, mean 56 years, } 44 \pm 20 \\
\text { postmenopausal }(n=307)\end{array}$ & $\begin{array}{c}\text { Age }>55 \text { years, calcium intake }<700 \mathrm{mg} / \mathrm{d}, \\
\text { wearing a veil, sunlight exposure }<30 \text { min/day }\end{array}$ \\
& &
\end{tabular}

$S D$ standard deviation

${ }^{\text {a }}$ Unless mentioned otherwise

Moroccan adult women in Morocco, who were measured at the end of winter, had a mean serum 25(OH)D concentration of $45 \mathrm{nmol} / \mathrm{l}$ [17]. This was lower than the indigenous population in the Netherlands (median $67 \mathrm{nmol} / \mathrm{l}$ ) and in Belgium (mean $49 \mathrm{nmol} / \mathrm{l}$ ) [1, 3]. The Dutch and Belgian populations consisted of both men and women, and these were measured year-round, which might explain the difference.

Studies on adult Indian (or South Asian) populations in Europe also found lower serum 25(OH)D concentrations in comparison to indigenous European populations (Table 5). Concerning pregnant women and children, we did not identify any studies which included an indigenous European population. The vitamin D status among various Indian populations in India differed (Table 6). Some populations with limited sunlight exposure, such as physicians and nurses (mean $8 \mathrm{nmol} / 1$ in winter and $18 \mathrm{nmol} / 1$ in summer) or Delhi-based males (mean $18 \mathrm{nmol} / \mathrm{l}$ ) and females (mean $17 \mathrm{nmol} / \mathrm{l})$ measured in winter, had low serum 25(OH)D concentrations, similar to Indian populations in Europe [18, 19]. Other, mainly rural, Indian adult populations in India had higher serum $25(\mathrm{OH}) \mathrm{D}$ concentrations [20, 21].

Sub-Saharan Africans in the Netherlands-consisting predominantly of Ghanaians and Somalis - had a median serum 25(OH)D concentration of $33 \mathrm{nmol} / \mathrm{l}(n=57)$ [1]. Congolese immigrants in Belgium had a mean serum 25 $(\mathrm{OH}) \mathrm{D}$ concentration of $38 \mathrm{nmol} / \mathrm{l}$ (standard deviation (SD) of $14 \mathrm{nmol} / \mathrm{l}$ ). We did not identify any studies on vitamin D status in Ghana, Somalia, or the Democratic Republic of Congo. Studies in sub-Saharan countries include a study in Cameroon, with a mean serum $25(\mathrm{OH}) \mathrm{D}$ concentration of $53 \mathrm{nmol} / \mathrm{l}$ (SD $19 \mathrm{nmol} / \mathrm{l}$ ) among an older population (aged 60-86 years), a study on Nigerian children (6-35 months) with a mean serum $25(\mathrm{OH}) \mathrm{D}$ concentration of $64 \mathrm{nmol} / \mathrm{l}(\mathrm{sd}$ $23 \mathrm{nmol} / \mathrm{l}$ ), and a study on Gambian women aged 25 or older, with a mean serum $25(\mathrm{OH}) \mathrm{D}$ concentration between $73 \mathrm{nmol} / \mathrm{l}$ (SD $20 \mathrm{nmol} / \mathrm{l}$ ) and $113 \mathrm{nmol} / \mathrm{l}$ (SD $27 \mathrm{nmol} / \mathrm{l})$, varying with age [22-24].
In all studies performed in Europe where both groups were included, immigrant groups in European countries had significantly lower serum $25(\mathrm{OH}) \mathrm{D}$ concentrations than indigenous European groups [1-4, 25-32].

\section{Determinants}

In the last column of each table, the determinants for a lower $25(\mathrm{OH}) \mathrm{D}$ concentration are presented. As expected, many studies found a lower exposure to sunlight (e.g., behavior or season) [1-3, 13-18, 27, 32-38] or a restricted intake of vitamin D (via food or supplements) [1, 14, 17, 33, 39, 40], to be associated with a lower serum $25(\mathrm{OH}) \mathrm{D}$ concentration.

Neither gender nor age were unambiguously associated with the serum $25(\mathrm{OH}) \mathrm{D}$ concentration. Female gender was found to be a determinant for a low serum 25(OH)D concentration $[2,4,15,33,35,36,41,42]$, but not in all studies that compared males and females [3, 19, 20, 31, 41, 43]. Both a younger age [33] and an older age [15, 17] were associated with a lower serum $25(\mathrm{OH}) \mathrm{D}$ concentration.

Other determinants of lower serum $25(\mathrm{OH}) \mathrm{D}$ concentrations - explained by association with exposure to sunlight or dietary habits - are a lower socioeconomic position [34, 42], a shorter duration of education [33, 39], or a lower educational level [14], living in an urban environment [20, 21], and an earlier start time to the workday [44].

In newborn children, a mother's lower serum 25(OH)D concentration was associated with a lower serum $25(\mathrm{OH}) \mathrm{D}$ concentration in the child $[18,45,46]$.

\section{Discussion}

The vitamin D status of Turkish, Moroccan, Indian, and sub-Sahara African immigrant populations in Europe was poor compared to the indigenous European populations. The vitamin D states of studied populations in Turkey, Morocco, and India varied between concentrations similar 


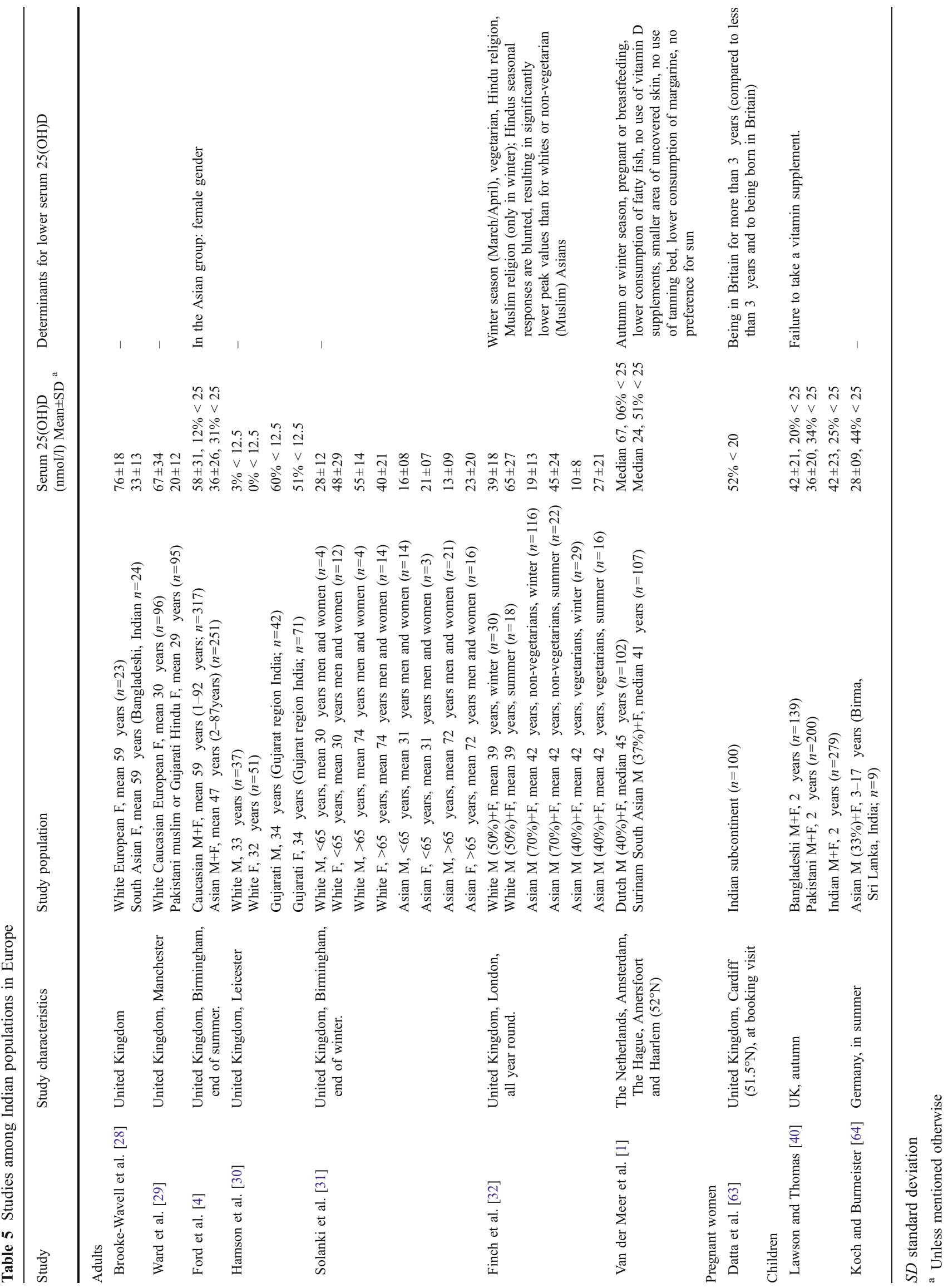




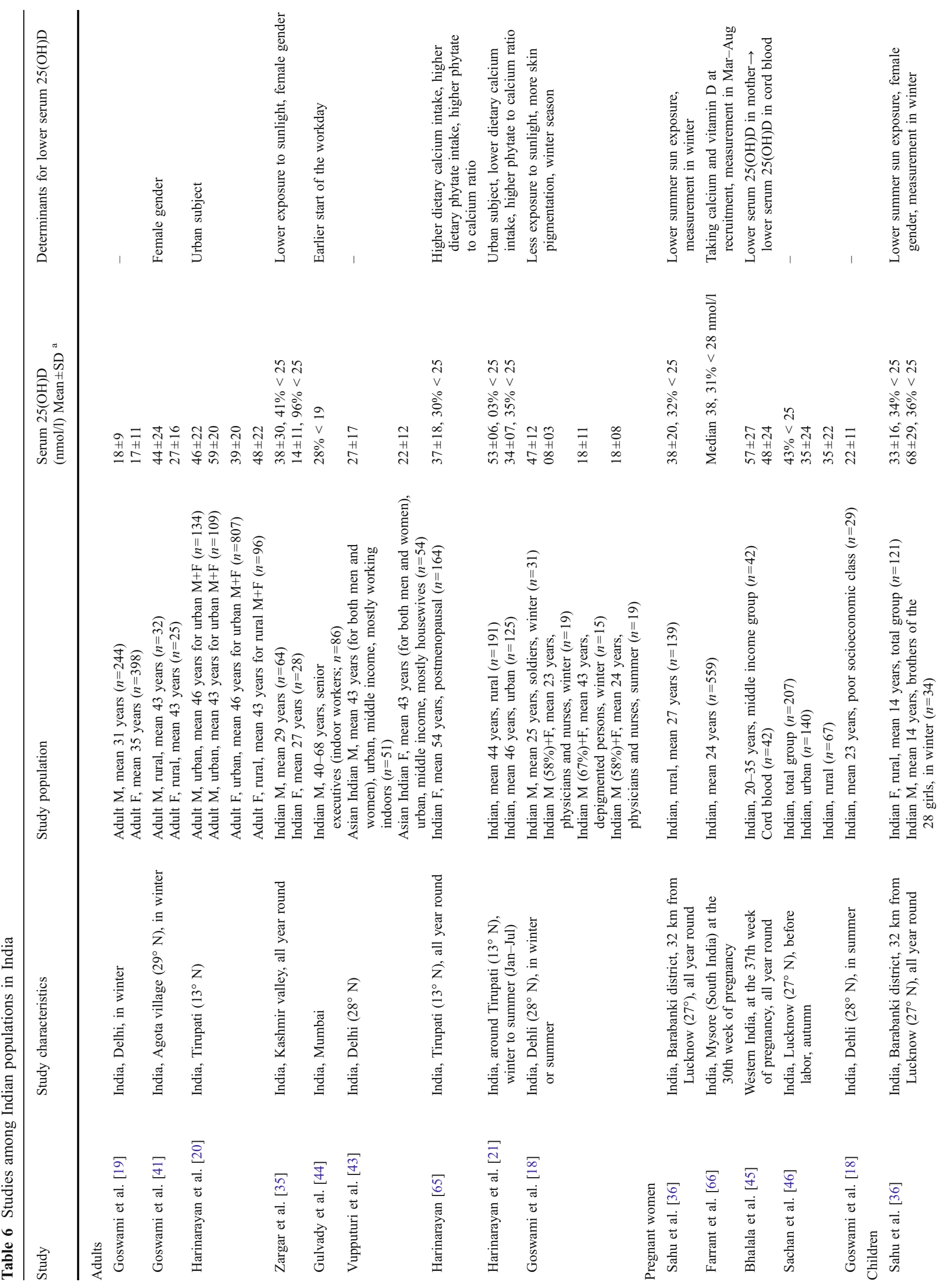



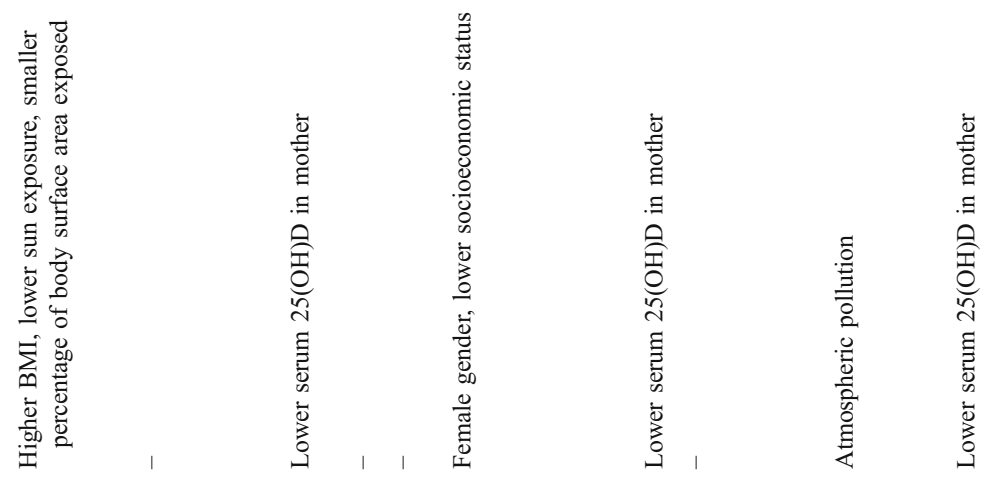

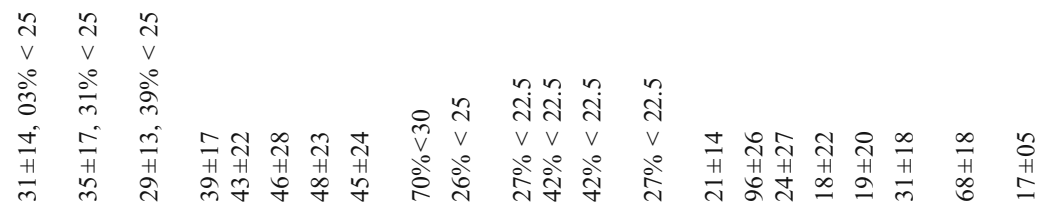

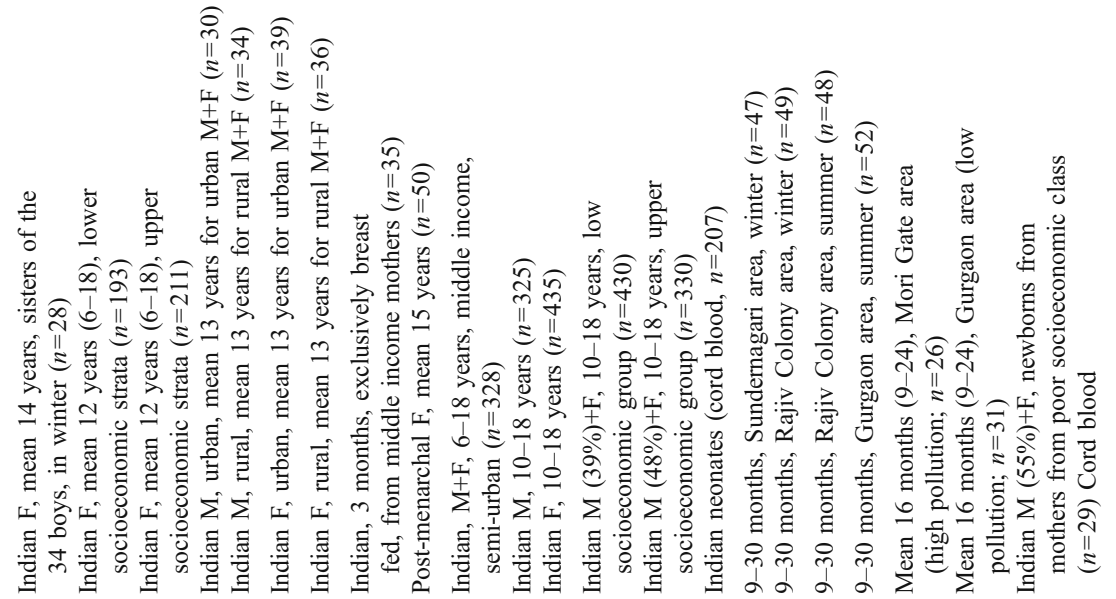

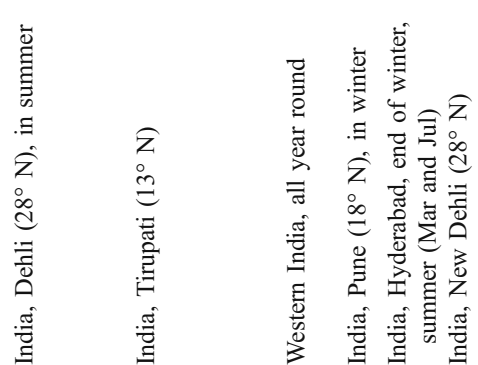

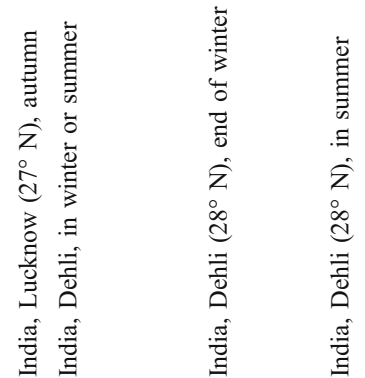

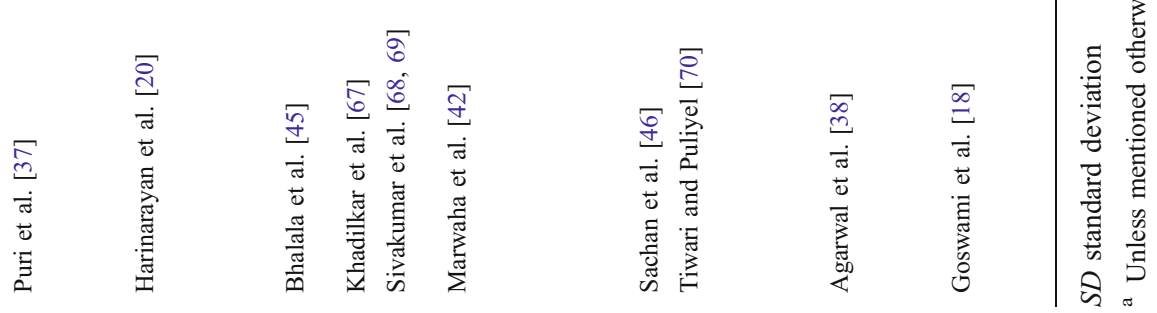


to the immigrant populations in Europe (low) and concentrations similar to or higher than the European indigenous populations (high). Determinants of the serum 25(OH)D concentration included both sources of vitamin D: exposure to sunlight and intake of vitamin D.

Gender and age were each associated with serum 25 $(\mathrm{OH}) \mathrm{D}$ concentration in both directions. Differences according to gender and age group could be the result of biological differences but might also reflect behavioral differences; dress style (e.g., wearing a veil) is often mentioned as a reason for a higher prevalence of vitamin D deficiency among women than men. A lower serum 25 (OH)D concentration among older participants can partly be the result of the lower capacity of the skin to produce vitamin $\mathrm{D}$ after exposure to sunlight. The study that found lower serum 25(OH)D concentrations at younger ages [33] might have had a study population that was too young to find an effect of a lower skin capacity (their mean age was below 40 years).

As the described studies were observational, not all determinants could be studied due to a lack of variation in the determinants. For instance, Sahu et al. described the dietary intake in rural India as remarkably monotonous from meal to meal, with a low consumption of dairy and foods containing reasonable amounts of vitamin D [36]. As a consequence, it is difficult to find an association between dietary intake and serum 25(OH)D.

The darker skin types of the immigrant populations are a suitable protection against the intensity and amount of sunlight in their countries of origin, while they are a risk factor for vitamin D deficiency in northerly European countries. The serum $25(\mathrm{OH}) \mathrm{D}$ concentrations of the populations in the country of origin may, therefore, indicate normal or reference concentrations. However, those populations may themselves be deficient or suffer from insufficient concentrations as a whole. Given that until recently, mankind lived and worked outside, the serum 25(OH)D concentrations of groups who currently spend much of their time outdoors might, therefore, be considered "normal" [47]. Serum $25(\mathrm{OH}) \mathrm{D}$ concentrations of rural populations, who are expected to have a greater exposure to sunlight as a result of their agricultural occupation than urban populations [20,21], might be a more suitable indicator of normal concentrations than those of total populations.

The high $(>100 \mathrm{nmol} / \mathrm{l})$ serum 25(OH)D concentrations in subgroups of two Turkish studies, which were performed at the end of the summer, suggest a large impact of sunlight. As sun exposure does not lead to toxic vitamin D concentrations due to a feedback mechanism, these serum 25(OH)D concentrations are expected to be within the normal or reference range, which is an additional argument that the low serum 25(OH)D concentrations (found in immigrant populations) can be interpreted as a deficiency.
Of course, assay differences might also explain part of the difference with other studies.

Symptomatic vitamin D deficiency is also suggested by the prevalence of rickets in Turkey, India, and some African countries [48-53]. The incidence of rickets in Eastern Turkey declined from $6.09 \%$ to $0.099 \%$ after a nationwide free vitamin D supplementation program [54]. Within European countries, rickets is not highly prevalent, but immigrant populations are groups at risk [55-57]. Additionally, although most nonwestern immigrant populations are younger than the indigenous European populations, cases of osteomalacia in nonwestern immigrants have been observed [58, 59]. Finch et al. found all but one case of osteomalacia within the vegetarian Asian group in England, the group with lowest vitamin D concentrations in their study [32]. Furthermore, osteoporotic and peripheral fractures were found in the vitamin-D-deficient subgroup in Morocco [17]. Erkal et al. found that $61 \%$ of the Turkish group (in Turkey) and $55 \%$ of the Turkish immigrant group in Germany complained of bone pain and/or nonspecific generalized muscle aches and pain, while it was $15 \%$ within the German group with higher serum 25(OH)D concentrations [2]. However, one should keep in mind that serum $25(\mathrm{OH}) \mathrm{D}$ is not the sole determinant of rickets; calcium intake is also important $[48,60,61]$.

The comparison of serum $25(\mathrm{OH}) \mathrm{D}$ concentrations of the various populations in this article has some limitations.

First, several studies present the prevalence of vitamin D deficiency but have excluded individuals using drugs or medication known to affect bone metabolism, those recently treated for vitamin D deficiency, or those who used vitamin D supplements [1, 2, 4, 14-17, 19, 28, 35, 37, 41-43]. Medications that affect bone metabolism include, among others, vitamin D and calcium. One can argue whether the presented values represent the real prevalence in the respective populations when these individuals are excluded. However, we expect the number of excluded individuals to be small and, therefore, not of great influence on the prevalence. Furthermore, it implies that the prevalence is applicable for an apparently healthy population.

Second, the season of blood sampling varies, and this might account for a part of the observed differences between studies, because the intensity of sunlight and the amount of sunlight per day varies between seasons. These differences may be larger when studies in European countries are part of the comparison, because seasonal differences in sunlight are expected to be higher in countries at higher latitudes. For that reason, the time of year was mentioned in the tables.

Third, the comparison is hampered because the serum 25 $(\mathrm{OH}) \mathrm{D}$ assessment methods differ, which may influence differences between groups [62]. In addition, the level of accuracy of studies within Europe and in the country of 
origin might differ. However, although we could not adjust for this type of bias, we presume that the differences will not be systematic or large enough to substantially alter the conclusions.

Finally, in comparing the various populations, it is important to realize that the social conditions of the immigrants might not be the same as those of the original populations. The cultural habits (skin-covering clothes, sun exposure, diet) might also change after immigration, particularly among the second generation.

Serum 25(OH)D concentrations of nonwestern immigrants in Europe and of subgroups of Turkish, Moroccan, Indian, and sub-Saharan countries are low. Ways to increase the serum 25(OH)D concentration include increased exposure to sunlight and increased intake of products that contain vitamin D. The strategy to effectuate these increases will differ in the various countries and populations and should be the subject of further study. These studies should ideally include measures of health to support the need for this increase in serum $25(\mathrm{OH}) \mathrm{D}$.

Acknowledgement We gratefully acknowledge René Otten of the VU University Medical Library for his assistance in searching the PubMed and Embase databases.

\section{Conflicts of interest None}

Open Access This article is distributed under the terms of the Creative Commons Attribution Noncommercial License which permits any noncommercial use, distribution, and reproduction in any medium, provided the original author(s) and source are credited.

\section{References}

1. van der Meer IM, Boeke AJ, Lips P, Grootjans-Geerts I, Wuister JD, Deville WL, Wielders JP, Bouter LM, Middelkoop BJ (2008) Fatty fish and supplements are the greatest modifiable contributors to the serum 25-hydroxyvitamin D concentration in a multiethnic population. Clin Endocrinol (Oxf) 68:466-472

2. Erkal MZ, Wilde J, Bilgin Y, Akinci A, Demir E, Bodeker RH, Mann M, Bretzel RG, Stracke H, Holick MF (2006) High prevalence of vitamin D deficiency, secondary hyperparathyroidism and generalized bone pain in Turkish immigrants in Germany: identification of risk factors. Osteoporos Int 17:1133-1140

3. Moreno-Reyes R, Carpentier YA, Boelaert M, El Moumni K, Dufourny G, Bazelmans C, Leveque A, Gervy C, Goldman S (2009) Vitamin D deficiency and hyperparathyroidism in relation to ethnicity: a cross-sectional survey in healthy adults. Eur J Nutr 48:31-37

4. Ford L, Graham V, Wall A, Berg J (2006) Vitamin D concentrations in an UK inner-city multicultural outpatient population. Ann Clin Biochem 43:468-473

5. Lips P (2006) Vitamin D physiology. Prog Biophys Mol Biol 92:4-8

6. Eriksen EF, Glerup H (2002) Vitamin D deficiency and aging: implications for general health and osteoporosis. Biogerontology 3:73-77
7. Holick MF (2007) Vitamin D deficiency. N Engl J Med 357:266281

8. Holick MF, MacLaughlin JA, Doppelt SH (1981) Regulation of cutaneous previtamin D3 photosynthesis in man: skin pigment is not an essential regulator. Science 211:590-593

9. Clemens TL, Adams JS, Henderson SL, Holick MF (1982) Increased skin pigment reduces the capacity of skin to synthesise vitamin D3. Lancet 1:74-76

10. Matsuoka LY, Wortsman J, Haddad JG, Hollis BW (1990) Skin types and epidermal photosynthesis of vitamin D3. J Am Acad Dermatol 23:525-526

11. Holick MF (1995) Environmental factors that influence the cutaneous production of vitamin D. Am J Clin Nutr 61:638S-645S

12. Lips $P$ (2005) How to define normal values for serum concentrations of 25-hydroxyvitamin D? An overview. In: Feldman D, Pike W, Glorieux FH (eds) vitamin D, 2nd edn. Elsevier, Amsterdam, pp 1019-1028

13. Alagol F, Shihadeh Y, Boztepe H, Tanakol R, Yarman S, Azizlerli H, Sandalci O (2000) Sunlight exposure and vitamin D deficiency in Turkish women. J Endocrinol Invest 23:173-177

14. Pehlivan I, Hatun S, Aydogan M, Babaoglu K, Gokalp AS (2003) Maternal vitamin D deficiency and vitamin D supplementation in healthy infants. Turk J Pediatr 45:315-320

15. Atli T, Gullu S, Uysal AR, Erdogan G (2005) The prevalence of Vitamin D deficiency and effects of ultraviolet light on Vitamin D levels in elderly Turkish population. Arch Gerontol Geriatr 40:53-60

16. Guzel R, Kozanoglu E, Guler-Uysal F, Soyupak S, Sarpel T (2001) Vitamin D status and bone mineral density of veiled and unveiled Turkish women. J Womens Health Gend Based Med 10:765-770

17. Allali F, El Aichaoui S, Khazani H, Benyahia B, Saoud B, El Kabbaj S, Bahiri R, Abouqal R, Hajjaj-Hassouni N (2009) High prevalence of hypovitaminosis $\mathrm{D}$ in Morocco: relationship to lifestyle, physical performance, bone markers, and bone mineral density. Semin Arthritis Rheum 38:444-451

18. Goswami R, Gupta N, Goswami D, Marwaha RK, Tandon N, Kochupillai N (2000) Prevalence and significance of low 25hydroxyvitamin D concentrations in healthy subjects in Delhi. Am J Clin Nutr 72:472-475

19. Goswami R, Marwaha RK, Gupta N, Tandon N, Sreenivas V, Tomar N, Ray D, Kanwar R, Agarwal R (2009) Prevalence of vitamin D deficiency and its relationship with thyroid autoimmunity in Asian Indians: a community-based survey. Br J Nutr 102:382-386

20. Harinarayan CV, Ramalakshmi T, Prasad UV, Sudhakar D (2008) Vitamin D status in Andhra Pradesh: a population based study. Indian J Med Res 127:211-218

21. Harinarayan CV, Ramalakshmi T, Venkataprasad U (2004) High prevalence of low dietary calcium and low vitamin D status in healthy south Indians. Asia Pac J Clin Nutr 13:359-364

22. Njemini R, Meyers I, Demanet C, Smitz J, Sosso M, Mets T (2002) The prevalence of autoantibodies in an elderly sub-Saharan African population. Clin Exp Immunol 127:99-106

23. Pfitzner MA, Thacher TD, Pettifor JM, Zoakah AI, Lawson JO, Isichei CO, Fischer PR (1998) Absence of vitamin D deficiency in young Nigerian children. J Pediatr 133:740-744

24. Aspray TJ, Yan L, Prentice A (2005) Parathyroid hormone and rates of bone formation are raised in perimenopausal rural Gambian women. Bone 36:710-720

25. Grootjans-Geerts I, Wielders JP (2002) A pilot study of hypovitaminosis D in apparently healthy, veiled, Turkish women: severe vitamin D deficiency in $82 \%$ [In Dutch: Pilotonderzoek naar hypovitaminose D bij ogenschijnlijk gezonde gesluierde Turkse vrouwen: ernstige vitamine D-deficiëntie bij $82 \%$ ]. Ned Tijdschr Geneeskd 146:1100-1101

26. van der Meer IM, Karamali NS, Boeke AJ, Lips P, Middelkoop BJ, Verhoeven I, Wuister JD (2006) High prevalence of vitamin D 
deficiency in pregnant non-Western women in The Hague, Netherlands. Am J Clin Nutr 84:350-353

27. Meulmeester JF, van den Berg H, Wedel M, Boshuis PG, Hulshof KF, Luyken R (1990) Vitamin D status, parathyroid hormone and sunlight in Turkish, Moroccan and Caucasian children in The Netherlands. Eur J Clin Nutr 44:461-470

28. Brooke-Wavell K, Khan AS, Taylor R, Masud T (2008) Lower calcaneal bone mineral density and broadband ultrasonic attenuation, but not speed of sound, in South Asian than white European women. Ann Hum Biol 35:386-393

29. Ward KA, Roy DK, Pye SR, O'Neill TW, Berry JL, Swarbrick CM, Silman AJ, Adams JE (2007) Forearm bone geometry and mineral content in UK women of European and South-Asian origin. Bone 41:117-121

30. Hamson C, Goh L, Sheldon P, Samanta A (2003) Comparative study of bone mineral density, calcium, and vitamin D status in the Gujarati and white populations of Leicester. Postgrad Med J 79:279-283

31. Solanki T, Hyatt RH, Kemm JR, Hughes EA, Cowan RA (1995) Are elderly Asians in Britain at a high risk of vitamin D deficiency and osteomalacia? Age Ageing 24:103-107

32. Finch PJ, Ang L, Colston KW, Nisbet J, Maxwell JD (1992) Blunted seasonal variation in serum 25-hydroxy vitamin D and increased risk of osteomalacia in vegetarian London Asians. Eur J Clin Nutr 46:509-515

33. Holvik K, Meyer HE, Haug E, Brunvand L (2005) Prevalence and predictors of vitamin D deficiency in five immigrant groups living in Oslo, Norway: the Oslo Immigrant Health Study. Eur J Clin Nutr 59:57-63

34. Olmez D, Bober E, Buyukgebiz A, Cimrin D (2006) The frequency of vitamin D insufficiency in healthy female adolescents. Acta Paediatr 95:1266-1269

35. Zargar AH, Ahmad S, Masoodi SR, Wani AI, Bashir MI, Laway BA, Shah ZA (2007) Vitamin D status in apparently healthy adults in Kashmir Valley of Indian subcontinent. Postgrad Med J 83:713-716

36. Sahu M, Bhatia V, Aggarwal A, Rawat V, Saxena P, Pandey A, Das V (2009) Vitamin D deficiency in rural girls and pregnant women despite abundant sunshine in northern India. Clin Endocrinol (Oxf) 70:680-684

37. Puri S, Marwaha RK, Agarwal N, Tandon N, Agarwal R, Grewal K, Reddy DH, Singh S (2008) Vitamin D status of apparently healthy schoolgirls from two different socioeconomic strata in Delhi: relation to nutrition and lifestyle. $\mathrm{Br} \mathrm{J}$ Nutr 99:876-882

38. Agarwal KS, Mughal MZ, Upadhyay P, Berry JL, Mawer EB, Puliyel JM (2002) The impact of atmospheric pollution on vitamin D status of infants and toddlers in Delhi, India. Arch Dis Child 87:111-113

39. Madar AA, Stene LC, Meyer HE (2009) Vitamin D status among immigrant mothers from Pakistan, Turkey and Somalia and their infants attending child health clinics in Norway. Br J Nutr 101:1052-1058

40. Lawson M, Thomas M (1999) Vitamin D concentrations in Asian children aged 2 years living in England: population survey. BMJ 318:28

41. Goswami R, Kochupillai N, Gupta N, Goswami D, Singh N, Dudha A (2008) Presence of 25(OH) D deficiency in a rural North Indian village despite abundant sunshine. J Assoc Physicians India 56:755-757

42. Marwaha RK, Tandon N, Reddy DR, Aggarwal R, Singh R, Sawhney RC, Saluja B, Ganie MA, Singh S (2005) Vitamin D and bone mineral density status of healthy schoolchildren in northern India. Am J Clin Nutr 82:477-482

43. Vupputuri MR, Goswami R, Gupta N, Ray D, Tandon N, Kumar N (2006) Prevalence and functional significance of 25-hydroxyvitamin
D deficiency and vitamin D receptor gene polymorphisms in Asian Indians. Am J Clin Nutr 83:1411-1419

44. Gulvady C, Pingle S, Shanbhag S (2007) Incidence of vitamin B12 / D3 deficiency among company executives. Indian J Occup Environ Med 11:83-85

45. Bhalala U, Desai M, Parekh P, Mokal R, Chheda B (2007) Subclinical hypovitaminosis D among exclusively breastfed young infants. Indian Pediatr 44:897-901

46. Sachan A, Gupta R, Das V, Agarwal A, Awasthi PK, Bhatia V (2005) High prevalence of vitamin D deficiency among pregnant women and their newborns in northern India. Am J Clin Nutr 81:1060-1064

47. Hollis BW (2005) Circulating 25-hydroxyvitamin D levels indicative of vitamin D sufficiency: implications for establishing a new effective dietary intake recommendation for vitamin D. J Nutr 135:317-322

48. Thacher TD, Fischer PR, Strand MA, Pettifor JM (2006) Nutritional rickets around the world: causes and future directions. Ann Trop Paediatr 26:1-16

49. Girish M, Subramaniam G (2008) Rickets in exclusively breast fed babies. Indian J Pediatr 75:641-643

50. el Hag AI, Karrar ZA (1995) Nutritional vitamin D deficiency rickets in Sudanese children. Ann Trop Paediatr 15:69-76

51. Tezer H, Siklar Z, Dallar Y, Dogankoc S (2009) Early and severe presentation of vitamin $\mathrm{D}$ deficiency and nutritional rickets among hospitalized infants and the effective factors. Turk J Pediatr 51:110-115

52. Echarri JJ, Bazeboso JA, Guillem-Grima F (2008) Rachitic deformities of lower members in congolese children. An Sist Sanit Navar 31:235-240

53. Prentice A (2008) Vitamin D deficiency: a global perspective. Nutr Rev 66:S153-S164

54. Ozkan B, Doneray H, Karacan M, Vancelik S, Yildirim ZK, Ozkan A, Kosan C, Aydin K (2009) Prevalence of vitamin D deficiency rickets in the eastern part of Turkey. Eur J Pediatr 168:95-100

55. Beck-Nielsen SS, Brock-Jacobsen B, Gram J, Brixen K, Jensen TK (2009) Incidence and prevalence of nutritional and hereditary rickets in southern Denmark. Eur J Endocrinol 160:491-497

56. Mallet E, Gaudelus J, Reinert P, Le Luyer B, Lecointre C, Leger J, Loirat C, Quinet B, Benichou JJ, Furioli J, Loeuille GA, Roussel B, Larchet M, Freycon F, Vidailhet M, Varet I (2004) Symptomatic rickets in adolescents. Arch Pediatr 11: 871-878

57. Yeste D, Carrascosa A (2003) Nutritional rickets in childhood: analysis of 62 cases. Med Clin (Barc) 121:23-27

58. Jensen JE, Hitz MF (2000) Osteomalacia-a frequently overlooked condition among refugees and immigrants. Ugeskr Laeger 162:6250-6251

59. Coster A, Ringe JD (2000) Osteomalacia in immigrants: therapeutic management of two cases. Med Klin (Munich) 95:451-456

60. Balasubramanian K, Rajeswari J, Gulab GYC, Agarwal AK, Kumar A, Bhatia V (2003) Varying role of vitamin D deficiency in the etiology of rickets in young children vs. adolescents in northern India. J Trop Pediatr 49:201-206

61. Pettifor JM (2004) Nutritional rickets: deficiency of vitamin D, calcium, or both? Am J Clin Nutr 80:1725S-1729S

62. Lips P, Chapuy MC, Dawson-Hughes B, Pols HA, Holick MF (1999) An international comparison of serum 25-hydroxyvitamin D measurements. Osteoporos Int 9:394-397

63. Datta S, Alfaham M, Davies DP, Dunstan F, Woodhead S, Evans J, Richards B (2002) Vitamin D deficiency in pregnant women from a non-European ethnic minority population-an interventional study. Bjog 109:905-908 
64. Koch HC, Burmeister W (1993) Vitamin D status of children and adolescents of African and Asian diplomats in Germany. Klin Padiatr 205:416-420

65. Harinarayan CV (2005) Prevalence of vitamin D insufficiency in postmenopausal south Indian women. Osteoporos Int 16:397-402

66. Farrant HJ, Krishnaveni GV, Hill JC, Boucher BJ, Fisher DJ, Noonan $\mathrm{K}$, Osmond C, Veena SR, Fall CH (2009) Vitamin D insufficiency is common in Indian mothers but is not associated with gestational diabetes or variation in newborn size. Eur J Clin Nutr 63:646-652

67. Khadilkar A, Das G, Sayyad M, Sanwalka N, Bhandari D, Khadilkar V, Mughal MZ (2007) Low calcium intake and hypovitaminosis D in adolescent girls. Arch Dis Child 92:1045
68. Sivakumar B, Vijayaraghavan K, Vazir S, Balakrishna N, Shatrugna V, Sarma KV, Nair KM, Raghuramulu N, Krishnaswamy K (2006) Effect of micronutrient supplement on health and nutritional status of schoolchildren: study design. Nutrition 22: S1-S7

69. Sivakumar B, Nair KM, Sreeramulu D, Suryanarayana P, Ravinder P, Shatrugna V, Kumar PA, Raghunath M, Rao VV, Balakrishna N, Kumar PU, Raghuramulu N (2006) Effect of micronutrient supplement on health and nutritional status of schoolchildren: biochemical status. Nutrition 22:S15-S25

70. Tiwari L, Puliyel JM (2004) Vitamin D level in slum children of Delhi. Indian Pediatr 41:1076-1077 